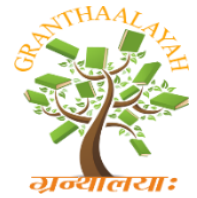

\author{
INTERNATIONAL JOURNAL OF RE
GRANTHAALAYAH \\ A knowledge Repository
}

Science

\title{
ADDITION OF PUMPKIN PEEL FLOUR AFFECT PHYSICOCHEMICAL AND SENSORY CHARACTERISTICS OF BOVINE BURGER
}

\author{
Giovanna Luiza Hartmann ${ }^{1}$, Allana Mariny Marconato ${ }^{1}$, Mirelly Marques Romeiro \\ Santos $^{2}$, Luane Aparecida do Amaral ${ }^{2}$, Elisvânia Freitas dos Santos 2,3, Daiana Novello 1,4* \\ ${ }^{1}$ Department of Nutrition, Universidade Estadual do Centro-Oeste. Guarapuava, Paraná, Brazil \\ 2 Postgraduate Program in Health and Development in the Midwest Region, Universidade \\ Federal de Mato Grosso do Sul. Campo Grande, Mato Grosso do Sul, Brazil \\ ${ }^{3}$ Faculty of Pharmaceutical Sciences, Food and Nutrition, Universidade Federal de Mato Grosso \\ do Sul. Campo Grande, Mato Grosso do Sul, Brazil \\ ${ }^{* 4}$ Postgraduate Program Interdisciplinary in Community Development, Universidade Estadual \\ do Centro-Oeste. Guarapuava, Paraná, Brazil
}

\begin{abstract}
The current study aimed to evaluate the influence of the addition of pumpkin peel flour (PPF) on physicochemical, cooking and sensory characteristics of bovine burger. Five hamburgers were formulated: F1 - standard (0\% PPF) and the others added 1\% (F2), 2\% (F3), 3\% (F4) and 4\% (F5) of PPF. The PPF was characterized by high contents of minerals, carbohydrate and dietary fiber, which improved nutritional profile of hamburger. There was an increase on cooking yield, moisture retention and reduction of shrinkage and fat retention, as the level of PPF addition increased. The incorporation of PPF at $3 \%$ and $4 \%$ in the product increased significantly $(\mathrm{p}<0.05)$ the values of $L^{*}, a^{*}$ and $b^{*}$. Similar acceptability to the standard sample was verified on products with addition of up to $3 \%$ PPF. All formulations showed an acceptability index greater than $70 \%$. Thus PPF is a potential ingredient for the formulation of bovine burger to improve its nutritional and technological properties without modification of the sensorial characteristics.
\end{abstract}

Keywords: Beef Burger; Enrichment; Meat Products.

Cite This Article: Giovanna Luiza Hartmann, Allana Mariny Marconato, Mirelly Marques Romeiro Santos, Luane Aparecida do Amaral, Elisvânia Freitas dos Santos, and Daiana Novello. (2020). “ADDITION OF PUMPKIN PEEL FLOUR AFFECT PHYSICOCHEMICAL AND SENSORY CHARACTERISTICS OF BOVINE BURGER.” International Journal of Research Granthaalayah, 8(2), 254-263. https://doi.org/10.29121/granthaalayah.v8.i2.2020.216.

\section{Introduction}

Meat and meat products have great nutritional importance in human food as they contain proteins of high biological value, vitamins mainly B6 and B12 and minerals such as zinc and iron. Although the population regularly consumes meat, studies have already shown its correlation with an 
increase in the prevalence of chronic pathologies, such as obesity and cardiovascular diseases [1,2]. In addition, processed meat products may be less nutritious than other types of food [3]. This fact does not prevent products such as hamburgers, sausages and nuggets from being highly accepted by consumers who seek for practicality and ready to eat.

Hamburgers are meat-based products. They are widely consumed by the most different publics, mainly due to their sensorial quality [4] and their practicality. However, these products may contain high levels of fats and calories, which may increase the risk of developing noncommunicable chronic diseases such as diabetes mellitus and some cancers [5]. Researches demonstrated the possibility of developing meat derivatives with differentiated ingredients, with a better nutritional profile. The addition of fruit and vegetable residues in hamburger is an example $[6,7]$. These by-products contain high levels of fiber, micronutrients and other substances such as antioxidants [8], which can be beneficial to health. Insoluble fibers, for example, help on body absorption of water and also in the regulation of intestinal transit [9]. However, food by-products is usually disposed by the final consumer, which increases the disposal of organic by-products in the environment. The valorization of these by-products as ingredients in meat products can increase the added economic value, besides collaborating for a healthier consumption and a better quality of life of the consumers.

The pumpkin is native of South America and belongs to the genus Cucurbita of Cucurbitaceae family. The most consumed genera are C. moschata, C. maxima and C. pepo. Orange pumpkin (Cucurbita maxima) stands out for its composition in fibers, carotenoids, vitamins and minerals [10]. This is widely grown and consumed in countries such as China, Thailand, Vietnam, Burma and India, and other tropical and subtropical countries [11], including Brazil. It is highly appreciated for its characteristic taste, versatility of preparation, and has good nutritional value [12]. The peel of pumpkin also stands out for its content in protein, vitamins, minerals and fibers [13]. Nevertheless, it is usually discarded while processing, due to lack of knowledge about their nutritional properties of the population. The use of peel of pumpkin in hamburgers can be a good industrial strategy to improve nutritional properties and benefit technological aspects related to viscosity, rheology and stability in meat products [14].

The aim of this research was to evaluate the influence of addition of pumpkin peel flour (PPF) on physicochemical, cooking and sensory characteristics of bovine burgers.

\section{Materials and Methods}

\section{Pumpkin Peel Flour (PPF) Processing}

Pumpkin of orange color ( $60 \mathrm{~kg}$ ) were used, with better visual appearance, smooth surface without imperfections and medium size. The whole pumpkins (Cucurbita maxima) were washed and immersed in sodium hypochlorite solution, with a proportion of $8 \mathrm{ml}$ for each liter of tape water. After 15 minutes, the pumpkins were rinsed under running tape water. Peels $(2 \mathrm{~mm}$ thick) were manually removed whit a knife and dried in a forced-air drier (Pardal, PE 60, Brazil) at $60{ }^{\circ} \mathrm{C}$ for 28 hours. The dried peels were grounded in a mill (Tecnal, Tec mill TE-633, Brazil), yielding 550 $\mathrm{g}$ of flour. The product was packed in plastic bags of low-density polyethylene and stored at - 18 ${ }^{\circ} \mathrm{C}$ until analyzes were carried out. 


\section{Beef Burger Processing and Cooking}

Five formulations of hamburgers added with different levels of PPF were prepared in triplicate: F1: standard (0\%), F2 (1\%), F3 (2\%), F4 (3\%) and F5 (4\%). These percentages were defined by means of preliminary sensory tests carried out on the product. In addition to the PPF percentages, the following ingredients were used: fresh beef (shoulder clod) (F1: 77.9\%, F2: 76.9\%, F3: 75.9\%, F4: $74.9 \%$, F5: 73,9\%), ice flakes (15\%), ground pork fat (5\%), sodium chloride (1.5\%), onion powder $(0.2 \%)$, garlic powder $(0.2 \%)$ and black pepper powder $(0.2 \%)$. For hamburgers elaboration, meat (approximately $65 \mathrm{~kg}$ ) was ground in a meat grinder (C.A.F., Brazil) on $3 \mathrm{~mm}$ disk and temperature about $4{ }^{\circ} \mathrm{C}$. Subsequently, ground beef was homogenized in a commercial blender (Super Cutter Sire, Brazil) for 1 minute at $8 \pm 1^{\circ} \mathrm{C}$. Onion, garlic, pepper, sodium chloride, ice flake and ground pork fat were added to the mixture and homogenized again for 3 minutes at $8 \pm 1{ }^{\circ} \mathrm{C}$. The PPF was incorporated into the mass and homogenized for an additional 3 minutes at $8 \pm 1{ }^{\circ} \mathrm{C}$. The resulting paste of each formulation was burger shaped (weight $100 \mathrm{~g}, 10 \mathrm{~cm}$ in diameter and $1 \mathrm{~cm}$ thick) using a hand fed hamburger (Picelli, HP 128, Brazil). The products were stored in plastic bags of low-density polyethylene and frozen in a conventional freezer (Electrolux, w35, Brazil) at $-18^{\circ} \mathrm{C}$ until the moment of analysis.

The frozen burgers were grilled on electric plate (Britânia Grill, Mega 2 N, Brazil) with grills on the upper and lower sides heated to $200{ }^{\circ} \mathrm{C}$ until a core temperature of $71{ }^{\circ} \mathrm{C}$ [15] controlled with a digital thermometer (Tp 101, Brazil). The average cooking time was 6 to 7 minutes.

\section{Consumer Study}

Participated in sensory analyses 60 untrained volunteer judges, hamburger usual consumers. Consumers had aged between 17 and 25 years and were recruited among students and staffs of Universidade Estadual do Centro-Oeste, Guarapuava, Paraná, Brazil. For conducting the sensory test, hamburgers have been cooked as previously described. All samples were evaluated by means of an acceptance test using a 9-point hedonic scale, with extremes ranging from dislike extremely (1) to like extremely (9) [16]. Were evaluated attributes related to appearance, aroma, flavor, color and texture, beyond overall acceptance. For the purchase intent test a 5-point attitude structured scale was used, varying from definitely would not buy it (1) to definitely would buy it (5) [16]. The sensory acceptability index (AI) was calculated by multiplying the average score reported by consumers to the product by 100 , dividing the result by the maximum average score given to the product within the hedonic scale for 9.0 points. Each sample $(15 \mathrm{~g})$ was served to consumers in white plates coded with randomly selected 3-digit numbers in monadic form and using balanced design [17]. Sensory evaluations were performed by consumers under fluorescence lighting. After consuming each sample, consumer was instructed to drink water for palate cleansing. Samples were evaluated in triplicate in separate session.

\section{Physicochemical Composition}

All analyzes were performed on three replicates in triplicate for PPF and for cooked hamburgers. Water activity (Aw) was determined using Aw analyzer (Novasina, Labswift model, Switzerland), at $20^{\circ} \mathrm{C}$. The $\mathrm{pH}$ was measured using a pH-meter (Tecnopon, MPA-210 model, Brazil). To stablish the color, five hamburgers were used per treatment, evaluated in five different points of the hamburger. The color was evaluated by the system of the Commission Internationale de L'Eclairage (CIE), lightness $\left(\mathrm{L}^{*}\right)$, redness $\left(\mathrm{a}^{*}\right)$, yellowness $\left(\mathrm{b}^{*}\right)$, colorimeter reading (Konica 
Minolta, Chroma Meter CR 4400 model, Japan) with illuminating calibration D65 and angle of observation $10^{\circ}$, previously calibrated.

Moisture, ash, protein, fat and dietary fiber content were determined by AOAC methods [18]. The moisture content was determined by drying in greenhouse $\left(105 \pm 2{ }^{\circ} \mathrm{C}\right)$. Ash was performed by muffle furnace. Protein was analyzed according to the Kjeldahl method. Factor 6.25 was used for conversion of nitrogen to crude protein in hamburger and PPF respectively. Fat content was determined according to the Soxhlet method, using petroleum ether. Total, soluble and insoluble dietary fiber was determined by the enzymatic method. The carbohydrate content was evaluated by means of theoretical calculation (by difference) in the results of the triplicates, according to the formula:

"\\% " carbohydrate= $100-$ ("\\% " moisture+"\\% " protein+"\\% " lipid+"\\% " ash+"\\% " fiber dietary)

The total caloric value (kcal) was calculated theoretically using Atwater factor [19] for lipid (9 kcal g-1), protein (4 kcal g-1) and carbohydrate (4 kcal g-1).

\section{Cooking Characteristics}

Five hamburgers from each formulation were cooked in the same procedure as mentioned previously then cooled to room temperature at $23{ }^{\circ} \mathrm{C}$ for $2 \mathrm{~h}$. Then cooled to room temperature at $23{ }^{\circ} \mathrm{C}$ for $2 \mathrm{~h}$. The following cooking characteristics were evaluated: cooking yield and the fat retention [20], shrinkage [21] and moisture retention [22]. The hamburgers were measured according to the following equations:

$\%$ cooking yield $=\frac{\text { weight of cooked sample }}{\text { weight of raw sample }} \times 100$

$\%$ fat retention $=\frac{(\text { weight of cooked sample }) \times(\% \text { fat in cooked sample })}{(\text { weight of raw sample }) \times(\% \text { fat in raw sample })} \times 100$

$\%$ shrinkage $=\frac{(\text { diameter of raw sample }- \text { diameter of cooked sample })}{\text { diameter of raw sample }} \times 100$

$\%$ moisture retention $=\frac{\% \text { cooking yield } \mathrm{x} \% \text { moisture content of cooked sample }}{100}$

\section{Statistical Analysis}

The results were analyzed using analysis of variance (ANOVA). The means were compared by Tukey's test at 5\% significance level $(\mathrm{p} \leq 0.05)$. The Software R was used to perform the statistical calculations.

\section{Ethical Issues}

The research was approved by the Ethics in Research Committee of UNICENTRO, Brazil, under the case number of 608.950/2014. 


\section{Results and Discussions}

\section{Consumer Study}

The results of the sensory test of grilled hamburger added at different levels of PPF are presented in Table 1.

Table 1: Sensory scores (mean \pm standard deviation) obtained for the hamburger with addition of different levels pumpkin peel flour (PPF)

\begin{tabular}{|l|c|c|c|c|c|}
\hline Parameters & F1 & F2 & F3 & F4 & F5 \\
\hline Appearance & $7.16 \pm 1.35^{\mathrm{a}}$ & $7.23 \pm 1.06^{\mathrm{a}}$ & $7.10 \pm 1.34^{\mathrm{a}}$ & $6.95 \pm 1.45^{\mathrm{a}}$ & $6.70 \pm 1.62^{\mathrm{a}}$ \\
\hline AI $(\%)$ & 79.56 & 80.33 & 78.89 & 77.22 & 74.44 \\
\hline Aroma & $7.33 \pm 1.05^{\mathrm{a}}$ & $7.35 \pm 1.31^{\mathrm{a}}$ & $7.30 \pm 1.33^{\mathrm{a}}$ & $7.10 \pm 1.32^{\mathrm{ab}}$ & $6.57 \pm 1.52^{\mathrm{b}}$ \\
\hline AI $(\%)$ & 81.44 & 81.67 & 81.11 & 78.89 & 73.00 \\
\hline Flavor & $7.52 \pm 1.05^{\mathrm{a}}$ & $7.43 \pm 1.28^{\mathrm{ab}}$ & $7.45 \pm 1.53^{\mathrm{ab}}$ & $7.21 \pm 1.33^{\mathrm{ab}}$ & $6.65 \pm 1.70^{\mathrm{b}}$ \\
\hline AI $(\%)$ & 83.56 & 82.56 & 82.78 & 80.11 & 73.89 \\
\hline Texture & $7.12 \pm 1.19^{\mathrm{a}}$ & $7.22 \pm 1.44^{\mathrm{a}}$ & $7.12 \pm 1.70^{\mathrm{a}}$ & $6.96 \pm 1.35^{\mathrm{a}}$ & $6.95 \pm 1.58^{\mathrm{a}}$ \\
\hline AI $(\%)$ & 79.11 & 80.22 & 79.11 & 77.33 & 77.22 \\
\hline Color & $7.09 \pm 1.38^{\mathrm{a}}$ & $7.13 \pm 1.33^{\mathrm{a}}$ & $7.13 \pm 1.41^{\mathrm{a}}$ & $6.88 \pm 1.46^{\mathrm{a}}$ & $6.80 \pm 1.34^{\mathrm{a}}$ \\
\hline AI $(\%)$ & 78.78 & 79.22 & 79.22 & 76.44 & 75.56 \\
\hline Overall Acceptance & $7.31 \pm 1.23^{\mathrm{a}}$ & $7.37 \pm 1.20^{\mathrm{a}}$ & $7.22 \pm 1.63^{\mathrm{ab}}$ & $6.91 \pm 1.58^{\mathrm{ab}}$ & $6.44 \pm 1.51^{\mathrm{b}}$ \\
\hline AI $(\%)$ & 81.22 & 81.89 & 80.22 & 76.78 & 71.56 \\
\hline Purchase Intention & $4.00 \pm 0.78^{\mathrm{a}}$ & $4.10 \pm 0.95^{\mathrm{a}}$ & $3.90 \pm 1.16^{\mathrm{a}}$ & $3.81 \pm 0.91^{\mathrm{a}}$ & $3.55 \pm 1.03^{\mathrm{a}}$ \\
\hline
\end{tabular}

Distinct letters in the same line indicate significant difference according to Tukey's test $(\mathrm{p}<0.05)$; AI: Acceptability Index. PPF addition: 0\% (F1); 1\% (F2); 2\% (F3); 3\% (F4); 4\% (F5).

There was no significant difference between formulations for appearance, texture, color and purchase intention $(\mathrm{p}>0.05)$. Higher scores for aroma were observed for F1, F2 and F3 when compared to F5. The F1 formulation was more accepted than F5 for flavor, while F1 and F2 were more accepted than F5 in regard to overall acceptance. Other samples did not show statistical difference among all the evaluated parameters ( $p>0.05)$. Similar results were observed whit papaya seed flour added to hamburger (0\% to $3 \%)$ [6] and in hamburger containing dry tomato peel $(0 \%$ to 6\%) [23]. The pumpkin peel has a pronounced aroma and residual taste, caused by polyphenols and cucurbitacins, a group of tetracyclic oxygenated triterpenes found in the genus Cucurbitaceae $[24,25]$. In addition, polymeric phenols found in the peel of vegetables, such as tannins, promote an astringent taste [26, 27]. These factors explain the lower acceptance of hamburgers containing high level of PPF. Similar effect was observed in studies that evaluated the addition of pea peel flour $(8 \%$ to $12 \%)$ in chicken nugget [14] and with addition of grape seed flour (0\% to $3 \%)$ in fermented sausage [28]. Moreover, PPF has an orange coloration, caused by the high content of carotenoids found in the peel of freeze-dried pumpkin, such as $\beta$-carotene (123.19 mg kg-1) [29], which alter hamburgers coloration (Figure 1). However, a significant reduction $(p>0.05)$ in the acceptance of this attribute by consumers after the addition of PPF was not observed. 


\section{Raw samples}

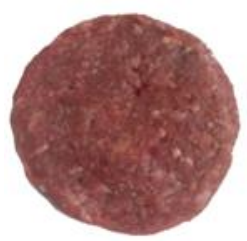

F1

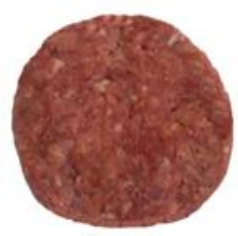

F2

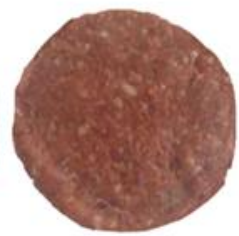

F3

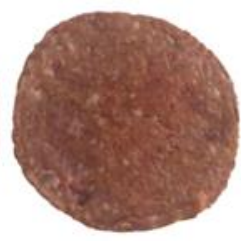

F4

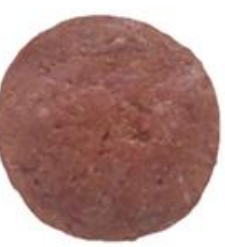

F5

\section{Cooked Samples}

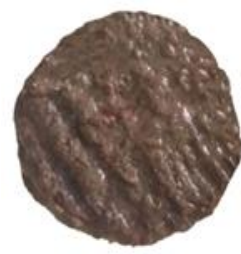

F1

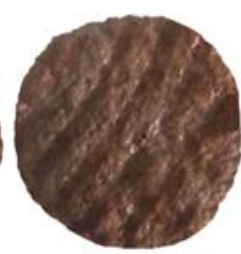

F2

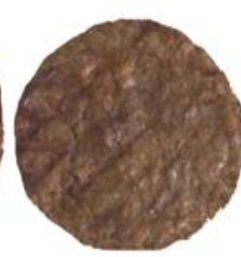

F3

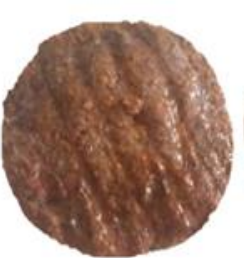

F4

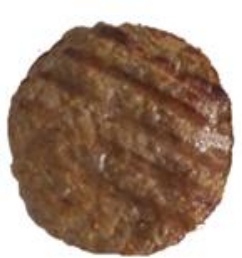

F5

Figure 1: Hamburger formulations with addition of different levels pumpkin peel flour (PPF): 0\% (F1); $1 \%$ (F2); $2 \%$ (F3); 3\% (F4); 4\% (F5).

All formulations exhibited AI above 70\%, demonstrating good sensorial acceptance [30]. Similar results were reported by Kaur et al. [31], whom added pomegranate seed flour (0\% to $3 \%)$ in chicken nugget. Thus, it is demonstrated the viability of using PPF as an ingredient in reformulated meat products, which promote consumption of healthier foods by the population, in addiction to reduce organic by-products.

\section{Physicochemical Composition}

Physicochemical composition of hamburgers is presented in Table 2.

Table 2: Physicochemical composition (mean \pm standard deviation) of pumpkin peel flour (PPF) and cooked hamburger with addition of different levels pumpkin peel flour (PPF)

\begin{tabular}{|c|c|c|c|c|c|c|}
\hline Parameters & PPF & F1 & F2 & F3 & F4 & F5 \\
\hline Moisture (g $\left.100 \mathrm{~g}^{-1}\right)$ & $2.62 \pm 0.03$ & $64.30 \pm 0.07^{\mathrm{b}}$ & $66.83 \pm 0.02^{\mathrm{a}}$ & $66.75 \pm 0.08^{\mathrm{a}}$ & $66.28 \pm 0.04^{\mathrm{a}}$ & $66.35 \pm 0.06^{\mathrm{a}}$ \\
\hline $\operatorname{Ash}\left(\mathrm{g} 100 \mathrm{~g}^{-1}\right)$ & $6.86 \pm 0.08$ & $1.88 \pm 0.04^{\mathrm{c}}$ & $2.31 \pm 0.03^{\mathrm{b}}$ & $2.30 \pm 0.02^{\mathrm{b}}$ & $2.40 \pm 0.04^{\mathrm{a}}$ & $2.41 \pm 0.07^{\mathrm{a}}$ \\
\hline Protein $\left(\mathrm{g} 100 \mathrm{~g}^{-1}\right)$ & $11.51 \pm 0.07$ & $21.52 \pm 0.04^{\mathrm{a}}$ & $19.05 \pm 0.04^{\mathrm{b}}$ & $18.58 \pm 0.03^{\mathrm{b}}$ & $18.03 \pm 0.01^{\mathrm{bc}}$ & $17.91 \pm 0.05^{\mathrm{c}}$ \\
\hline Lipid & $6.65 \pm$ & $9.26 \pm 0.06^{\mathrm{a}}$ & $8.27 \pm 0.08^{\mathrm{b}}$ & $8.24 \pm 0.09^{b}$ & & $8.47 \pm 0.10^{\mathrm{b}}$ \\
\hline & $72.36 \pm 0$ & $3.03 \pm 0.32^{\mathrm{d}}$ & $3.54 \pm 0.19^{c}$ & $4.13 \pm 0.35^{\mathrm{bc}}$ & $4.89 \pm 0.47^{\mathrm{a}}$ & $4.86 \pm 0.36^{\mathrm{a}}$ \\
\hline Ener & $395.35 \pm 1$ & $181.56 \pm 1.87^{\mathrm{a}}$ & $164.81 \pm 1.68^{\mathrm{b}}$ & $164.98 \pm 1.89^{\mathrm{b}}$ & $167.27 \pm 1.85^{\circ}$ & $167.28 \pm 1.99^{\circ}$ \\
\hline Solu & $1.76 \pm 0$ & ND & $0.02 \pm 0.09^{\mathrm{b}}$ & $0.04 \pm 0.10^{\mathrm{b}}$ & $0.05 \pm 0.08^{\mathrm{ab}}$ & $0.07 \pm 0.07^{\mathrm{a}}$ \\
\hline efiber $\left(\mathrm{g} 100 \mathrm{~g}^{-1}\right)^{* * * *}$ & $33.05 \pm 0.11$ & ND & $0.33 \pm 0.08^{\mathrm{d}}$ & $0.66 \pm 0.09^{\mathrm{c}}$ & $0.99 \pm 0.10^{\mathrm{b}}$ & $1.32 \pm 0.11^{\mathrm{a}}$ \\
\hline & 34.81 & ND & & & & $1.39 \pm 0.10^{\mathrm{a}}$ \\
\hline $\mathrm{pH}$ & $5.99=$ & $0.22 \pm 6$ & & & & $5.85 \pm 0.05^{\mathrm{a}}$ \\
\hline Water a & $0.40 \pm 0.05$ & $0.97 \pm 0.06^{\mathrm{a}}$ & $0.97 \pm 0.02^{\mathrm{a}}$ & $0.97 \pm 0.01^{\mathrm{a}}$ & $0.97 \pm 0.02^{\mathrm{a}}$ & $0.97 \pm 0.02^{\mathrm{a}}$ \\
\hline
\end{tabular}

Distinct letters in the same line indicate significant difference according to Tukey's test $(\mathrm{p}<0.05)$; PPF addition: 0\% (F1); 1\% (F2); 2\% (F3); 3\% (F4); 4\% (F5). Values calculated in dry basis; *Include dietary fiber; **Theoretical calculations: lipid (9 kcal g-1), protein (4 kcal g-1) and carbohydrate (4 kcal g-1); ***Dietary fiber; ND: not detected. 
Moisture, ash, carbohydrate and fiber contents increased when PPF was added. The higher moisture content can be explained by hydration properties of fiber and also by its porous and hydrophilic nature, factors that increase water retention in the fiber matrix [32]. The PPF contains higher carbohydrate and mineral contents, such as iron (42.99 $\pm 0.10 \mathrm{mg} 100 \mathrm{~g}-1)$ and phosphorus (319.33 $\pm 0.05 \mathrm{mg} 100 \mathrm{~g}-1$ ) [33] compared to meat [34], which favors the increase of minerals and carbohydrate in the hamburger. Protein, lipid and caloric value were lower for hamburger added with different levels of PPF.

There was no significant difference between Aw of the different formulations. However, the addition of PPF raised $\mathrm{pH}$ in the hamburger, opposite of what observed by García et al. [23], after the addition of dried tomato peel $(6 \%)$ in hamburger. This authors attributed this effect to the low $\mathrm{pH}$ values of the dry tomato peel (4.43), when compared to the meat that is around 5.5 [35]. In the case of PPF, the $\mathrm{pH}$ is even higher (5.99). Likewise Newton and Gill [36] explained, a high $\mathrm{pH}$ does not accelerate the growth of deteriorating microorganisms, but it reduces latency time. In addition, increasing $\mathrm{pH}$ in meat products may lead to increased redness, causing darker meat [37] and increase water retention [38], which interferes on the product texture, leading to greater softness [39]. The instrumental color parameters of cooked hamburgers are presented in Table 3.

Table 3: Color parameters $\mathrm{L}^{*}, \mathrm{a}^{*} \mathrm{e} \mathrm{b}^{*}$ (mean \pm standard deviation) of cooked hamburgers with addition of different levels pumpkin peel flour (PPF)

\begin{tabular}{|l|c|c|c|}
\hline Formulation & Lightness $\left(\boldsymbol{L}^{*}\right)$ & Redness $\left(\boldsymbol{a}^{*}\right)$ & Yellowness $\left(\boldsymbol{b}^{*}\right)$ \\
\hline F1 & $43.51 \pm 0.08^{\mathrm{b}}$ & $4.99 \pm 0.05^{\mathrm{b}}$ & $6.19 \pm 0.22^{\mathrm{c}}$ \\
\hline F2 & $43.35 \pm 0.59^{\mathrm{b}}$ & $4.93 \pm 0.20^{\mathrm{b}}$ & $7.79 \pm 0.27^{\mathrm{b}}$ \\
\hline F3 & $43.43 \pm 1.23^{\mathrm{b}}$ & $4.90 \pm 0.31^{\mathrm{b}}$ & $8.07 \pm 0.35^{\mathrm{b}}$ \\
\hline F4 & $46.25 \pm 0.79^{\mathrm{a}}$ & $5.39 \pm 0.19^{\mathrm{a}}$ & $11.09 \pm 0.55^{\mathrm{a}}$ \\
F5 & $45.54 \pm 0.22^{\mathrm{a}}$ & $5.50 \pm 0.27^{\mathrm{a}}$ & $11.32 \pm 0.57^{\mathrm{a}}$ \\
\hline
\end{tabular}

Distinct letters in the same column indicate significant difference according to Tukey's test (p<0.05); PPF addition: 0\% (F1); 1\% (F2); 2\% (F3); 3\% (F4); 4\% (F5).

The addition of higher levels of PPF $(3 \%$ and $4 \%)$ increased $(\mathrm{p}<0.05)$ values of $\mathrm{L}^{*}, \mathrm{a}^{*}$ and $\mathrm{b}^{*}$. There was no significant difference for $\mathrm{L}^{*}$ and $\mathrm{a}^{*}$ between formulations F1, F2 and F3. However, $\mathrm{F} 1$ showed lower level of yellowness ( $\mathrm{b}^{*}$ ) than F2 and F3, since it does not contain PPF. In general, the addition of levels $\geq 3 \%$ of PPF in hamburger promoted a lightness, redness and yellowness of the product. It occurs due to the presence of compounds in the peel, such as chlorophyll, carotenoids and flavonoids, which act as natural colorants in fruits and vegetables [40]. Similar results were reported by García et al. [23], after the addition of $1.5 \%$ of dried tomato peel in hamburger, except the reduction in lightness.

\section{Cooking Characteristics}

The results of cooking characteristics of hamburgers are show in Table 4. 
Table 4: Cooking characteristics (mean \pm standard deviation) of cooked hamburger with addition of different levels pumpkin peel flour (PPF)

\begin{tabular}{|l|c|c|c|c|}
\hline Formulation & $\begin{array}{c}\text { Cooking } \\
\text { Yield (\%) }\end{array}$ & $\begin{array}{c}\text { Fat } \\
\text { Retention (\%) }\end{array}$ & $\begin{array}{c}\text { Shrinkage } \\
(\boldsymbol{\%})\end{array}$ & $\begin{array}{c}\text { Moisture Retention } \\
(\boldsymbol{\%})\end{array}$ \\
\hline F1 & $70.62 \pm 0.13^{\mathrm{d}}$ & $81.91 \pm 0.22^{\mathrm{a}}$ & $19.05 \pm 0.14^{\mathrm{a}}$ & $45.58 \pm 0.16^{\mathrm{d}}$ \\
\hline F2 & $70.26 \pm 0.51^{\mathrm{d}}$ & $79.32 \pm 0.29^{\mathrm{b}}$ & $19.55 \pm 1.93^{\mathrm{a}}$ & $51.60 \pm 0.56^{\mathrm{c}}$ \\
\hline F3 & $80.46 \pm 0.12^{\mathrm{c}}$ & $77.56 \pm 0.45^{\mathrm{bc}}$ & $19.28 \pm 0.40^{\mathrm{a}}$ & $55.00 \pm 0.30^{\mathrm{b}}$ \\
\hline F4 & $84.82 \pm 0.10^{\mathrm{b}}$ & $75.45 \pm 0.32^{\mathrm{cd}}$ & $17.95 \pm 0.08^{\mathrm{b}}$ & $56.29 \pm 0.01^{\mathrm{a}}$ \\
\hline F5 & $87.80 \pm 0.13^{\mathrm{a}}$ & $72.56 \pm 0.56^{\mathrm{d}}$ & $16.13 \pm 0.33^{\mathrm{b}}$ & $56.71 \pm 0.09^{\mathrm{a}}$ \\
\hline
\end{tabular}

Distinct letters in the same column indicate significant difference according to Tukey's test ( $\mathrm{p}<0.05)$; PPF addition: 0\% (F1); 1\% (F2); $2 \%(\mathrm{~F} 3) ; 3 \%(\mathrm{~F} 4) ; 4 \%(\mathrm{~F} 5)$.

The cooking yield and moisture retention in the hamburger increased significantly with the addition of PPF. Moreover, there was a reduction in the shrinkage percentage with 3\% and 4\% PPF. The higher moisture retention can be attributed to the amount of PPF fibers. The fibers have the ability to interact with meat proteins, creating a network that prevents migration of water from the product to the surface [41]. It increases cooking efficiency and reduces shrinkage of the burger. The PPF samples had a lower fat retention than the standard formulation $(\mathrm{p}<0.05)$, corroborating with Azevedo and Campagnol [6]. This fact can be attributed to fibers, which may exhibit preferential binding to water [41] rather than fat.

\section{Conclusions}

The PPF can be used as an ingredient in the bovine burger formulation, since it contains high nutritional value, which increases the levels of minerals, carbohydrate and dietary fiber in the meat product. It also has a favorable influence on the technological characteristics of the hamburger, increasing cooking yield and moisture retention, as well as reducing fat retention and shrinkage. A level of addition up to $3 \%$ of PPF in products maintains acceptability similar to the standard sample. Nevertheless, all formulations have an acceptability index greater than $70 \%$. The use of flour by-products in hamburger should be encouraged as it can improve their nutritional and technological characteristics and maintain sensory acceptability. In addition, it reduces the negative effects of organic by-products disposal on the environment.

\section{Acknowledgements}

The authors thank the Araucaria Foundation of Supports Scientific and Technological Development in the State of Paraná, Brazil for financial support.

\section{References}

[1] Ley SH, Sun O, Willet WC, Eliassen AH, Wu K, Pan A, Grodstein F, Hu FB. Associations between red meat intake and biomarkers of inflammation and glucose metabolism in women. American Journal of Clinical Nutrition. 2013;99(2):352-360.

[2] Klurfeld DM. Research gaps in evaluating the relationship of meat and health. Meat Science. 2015;109(1):86-95.

[3] Jiang J, Xiong YL. Natural antioxidants as food and feed additives to promote health benefits and quality of meat products: A review. Meat Science. 2016;120(1):107-117. 
[4] Eltilib HH, Elgasim EA, Mohamed Ahmed IA. Effect of incorporation of Cyperus rotundus L. rhizome powder on quality attributes of minced beef meat. Journal Food Science Technology. 2016;53(9):3446-3454.

[5] Boada LD, Henríquez-Hernández LA, Luzardo OP. The impact of red and processed meat consumption on cancer and other health outcomes: Epidemiological evidences. Food and Chemical Toxicology. 2016;92(1): 236-244.

[6] Azevedo LA, Campagnol PCB. Papaya seed flour (Carica papaya) affects the technological and sensory quality of hamburgers. International Food Research Journal. 2014;21(6):2141-2145.

[7] Mohamed FK, Sobhy HM, Azer WZ, Ezz El-Din Manal M, Ali HMZ, El-Askalany SA. Fatty acid profile, antioxidant activity of various suggested chicken burger treatments. Annals of Agriculture Science. 2014;59(1):47-51.

[8] Khattak A, Ullah F, Wazir SM, Shinwari ZK. Allelopathic potential of jatropha curcas 1. leaf aqueous extracts on seedling growth of wheat. Pakistan Journal of Botany. 2015;47(6):2449-2454.

[9] McRorie Jr JW, Mckeown NM. Understanding the Physics of Functional Fibers in the Gastrointestinal Tract: An Evidence-Based Approach to Resolving Enduring Misconceptions about Insoluble and Soluble Fiber. Journal of the Academy of Nutrition and Dietetics. 2016;117(2):251264.

[10] Kaźmińska K, Sobieszek K, Targońska-Karasek M, Korzeniewska A, Niemirowicz-Szczytt K, Bartoszewski G. Genetic diversity assessment of a winter squash and pumpkin (Cucurbita maxima Duchesne) germplasm collection based on genomic Cucurbita-conserved SSR markers. Scientia Horticulturae. 2017;219(17):37-44.

[11] Yenda B, Rao BV, Rao GB. In Vitro Antioxidant Activity Studies on Leaves of Cucurbita maxima. International Journal of Advanced Research in Science and Technology. 2015;4(1):241-244.

[12] Paris SH. Overview of the origins and history of the five major cucurbit crops: issues for ancient DNA analysis of archaeological specimens. Vegetation History and Archaeobotany. 2016;25(4):405-414.

[13] Staichok ACB, Mendonça KRB, Santos PGA, Garcia LGC, Damiani C. Pumpkin Peel Flour (Cucurbita máxima L.) Characterization and Technological Applicability. Journal of Food and Nutrition Research. 2016;4(5):327-333.

[14] Verma AK, Banerjee R, Sharma BD. Quality characteristics of low fat chicken nuggets: effect of salt substitute blend and pea hull flour. Journal Food Science Technology. 2015;52(4):2288-2295.

[15] American Meat Science Association (AMSA). Research guidelines for cookery, sensory evaluation and instrumental tenderness measurements of meat. 2 ed. Champaign: American Meat Science Association; 2015.

[16] Meilgaard M, Civille GV, Carr BT. Sensory evaluation techniques. 3nd ed. Boca Raton: CRC; 1999.

[17] Macfie HJ, Bratchell N, Greenhof K, Vallis LV. Designs to balance the effect of order of presentation and first-order carry over effects in hall tests. Journal of Sensory Studies. 1989;4(2):129-148.

[18] Association of Official Agricultural Chemists (AOAC) International. Official Methods of Analysis of AOAC International. Gaithersburg: Association of Official Analytical Chemists; 2011.

[19] Atwater WO, Woods CD. The chemical composition of American food materials. US Official Experiment Stations. Experiment Station Bulletin. 1896;28(1):461-462.

[20] Murphy EW, Criner PE, Gray BC. Comparisons of methods for calculating retentions of nutrients in cooked foods. Journal of Agricultural and Food Chemistry. 1975;23(6):1153-1157.

[21] Berry BW. Low fat level effects on sensory, shear, cooking, and chemical properties of ground beef patties. Journal of Food Science. 1992;57(3): 537-540.

[22] El-Magoli SB, Laroia S, Hansen PTM. Flavour and texture characteristics of low fat ground beef patties formulated with whey protein concentrate. Meat Science. 1996;42(2):179-193. 
[23] Ferguson JE, Metcalf RL. Cucurbitacins Plant-Derived Defense Compounds for Diabroticites (Coleoptera: Chrysomelidae). Journal of Chemical Ecology. 1985;11(3):311-318.

[24] Ajila CM, Leelavathi K, Prasada, RUJS. Improvement of dietary fiber content and antioxidant properties in soft dough biscuits with the incorporation of mango peel powder. Journal of Cereal Science. 2008;48(2):319-326.

[25] García LM, Calvo MM, Selgas MD. Beef hamburgers enriched in lycopene using dry tomato peel as an ingredient. Meat Science. 2009;83(1):45-49.

[26] Strumeyer DH, Malin MJ. Condensed tannins in grain sorghum: isolation, fractionation, and characterization. Journal of Agricultural and Food Chemistry. 1975;23(5):909-914.

[27] Salunkhe DK, Chavan JK. Dietary tannins: consequences and remedies. Boca Raton: CRC Press; 1990.

[28] Kurt Ş. The Effects of Grape Seed Flour on the Quality of Turkish Dry Fermented Sausage (Sucuk) during Ripening and Refrigerated Storage. Korean Journal for Food Science of Animal Resources. 2016;36(3):300-308.

[29] Kim MY, Kim EJ, Kim YN, Choi C, Lee BH. Comparison of the chemical compositions and nutritive values of various pumpkin (Cucurbitaceae) species and parts. Nutrition Research and Practice. 2012;6(1):21-27.

[30] Corradini SAS, Madrona GS, Visentainer JV, Bonafe EG, Carvalho CB, Roche PM, Prado IN. Sensorial and fatty acid profile of ice cream manufactured with milk of crossbred cows fed palm oil and coconut fat. Journal of Dairy Science. 2014;97(11):6745-6753.

[31] Kaur S, Kumar S, Bhat ZF. Utilization of pomegranate seed powder and tomato powder in the development of fiber-enriched chicken nuggets. Nutrition \& Food Science. 2015;45(5):793-807.

[32] Figuerola F, Hurtado ML, Estévez AM, Chiffelle I, Fasenjo F. Fibre concentrates from apple pomace and citrus peel as potential fibre sources for food enrichment. Food Chemistry. 2005;91(3):395-401.

[33] Mala KS, Kurian AE. Nutritional composition and antioxidant activity of pumpkin wastes. International Journal of Pharmaceutical, Chemical and Biological Sciences. 2016:6(3):336-344.

[34] United States Department of Agriculture (USDA). USDA Food Composition Databases. July, 2018. Retrieved on January 24, 2019. Website: https://ndb.nal.usda.gov/ndb/search/list.

[35] Van Der Wal PG, Bolink AH, Merkus GSM. Differences in quality characteristics of normal, PSE and DFD pork. Meat Science. 1988;24(1):79-84.

[36] Newton KG, Gill CO. The microbiology of DFD fresh meats: A review. Meat Science, 1981;5(3):223-232.

[37] Yang CC, Chen TC. Effects of refrigerated storage, $\mathrm{pH}$ adjustment, and marinade on color of raw and microwave cooked chicken meat. Poultry Science. 1993;72(2):355-362.

[38] Cheng Q, Sun D. Factors Affecting the Water Holding Capacity of Red Meat Products: A Review of Recent Research Advances. Critical Reviews in Food Science and Nutrition. 2008;48(2):137159.

[39] Guerrero L, Gou P, Arnau J. The influence of meat $\mathrm{pH}$ on mechanical and sensory textural properties of dry-cured ham. Meat Science. 1999;52(3):267-273.

[40] Tadmor Y, Burger J, Yaakov Y, Feder A, Libhaber SE, Portnoy V, Meir A, Tzuri G, Sa'ar U, Rogachev I, Aharoni A, Abeliovich H, Schaffer AA, Lewinsohn E, Katzir N. Genetics of flavonoid, carotenoid, and chlorophyll pigments in melon fruit rinds. Journal of Agricultural and Food Chemistry. 2010;58(19):10722-10728.

[41] Anderson ET, Berry BW. Effects on inner pea fiber on fat retention and cooking yield in high fat ground beef. Food Research International. 2001;34(8):689-694.

${ }^{*}$ Corresponding author.

E-mail address: nutridai@gmail.com 